University of Louisville

ThinkIR: The University of Louisville's Institutional Repository

Electronic Theses and Dissertations

$1-1929$

\title{
Sketches of Robert Browning's women.
}

Mame Morris Boulware

University of Louisville

Follow this and additional works at: https://ir.library.louisville.edu/etd

\section{Recommended Citation}

Boulware, Mame Morris, "Sketches of Robert Browning's women." (1929). Electronic Theses and Dissertations. Paper 132.

https://doi.org/10.18297/etd/132

This Master's Thesis is brought to you for free and open access by ThinkIR: The University of Louisville's Institutional Repository. It has been accepted for inclusion in Electronic Theses and Dissertations by an authorized administrator of ThinkIR: The University of Louisville's Institutional Repository. This title appears here courtesy of the author, who has retained all other copyrights. For more information, please contact thinkir@louisville.edu. 
UNITRRSITY OF IOUISVILIE

SKATCHES OF ROBERT BROWIITG'S WOIEN

\author{
A Dissertation \\ Submitted to the Faculty \\ Of the Graduate School of the College of Liberal Arts \\ In Partial Fulfillment of the \\ Requirements for the Degree \\ of liaster of Arts
}

Department of English

By

(Mrs.) Name Morris Boulware 
SKITCHIS OF ROBERT BRONITGG'S HOMOH 
TABLE OF CONTENTS

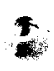

4 
TABLE OF CONTENTS - CONTINUED

FAITH AND CONSTANCY

ANAEL: RETURN OF THE DRUSES

33.

ELVIRE: FIFINE AT THE FAIR

41.

UNRTHARDED LOVZ

DUCHESS OF FERRARA: MY LAST DUCHESS

44.

THE QUEEN: IN A BALCONY

45.

THE YOUNG DUCHESS: THE FLIGHT OF THE DUCHESS

47.

JAMES LEE'S WIFE: JAMES LEE'S WTFE

49.

THE UNFORTUNATES

MILDRTD : BLOT IN THF 'SCUTCHEON

53.

GIRL IN THE CONFESSIONAL

55.

WIFE OF RICARDO: THE STATUE AND BUST

56.

TABBY BRATTS : NED BRATTS

57.

CLARA : RBD COTTON NIGHT- CAP COUNTRY

58.

OTTIMA: PIPPA PASSES

60. 


\section{GTRLHOOD}

PIPPA: PLPPA PASSTS

BALASTOT: BATASTIOTS ADVENTURE

DVETYN HUPE: EVSEY HOPE

TIE GIRL IN IHE IAST RIDE TOGETYAR

EUTLIIA: SOUL'S TRAGEDY

$+$ 


\section{Girlhood.}

No other poet has given to the world such a diversity of woman characters as has Robert Browning. Longing for variety he represents his womanhood, not in classes but by individual

differentiation; he portrays the simple, the complex, the subtle, the perticular, the impulsive and others-men distinct from the rest.

Browning emphasizes natural charms less than intellectual and moral loveliness. He strives to depict women as they are in themselves. By suggestions of spiritual nature, by delicate workmanship, he sets his feminine character before us. With dexterous versatility he creates type after type, each a character in herself. Two of the important dramas, Pippa Passes and Columbe's Birthday are named for women. More than twenty of the poems have titles or suggestions of women's names.

Browning places woman side by side with man. He considers her as important and as interesting, placing her sometimes in situations where she is instrumental in bringing about the catastrophe of the drama. There is no patronage but a candid admission of mutual help and assistance. Again and again it is the feminine character who sees the truth and impresses it upon the men in the story. Some of his women characters are keenly suscoptible to the influence of flowers, skies, landscapes; it is from them we get in Browming some descriptive passages that are filled with great beauty.

Most of Browning's heroines are intellectual; many of them 
are suffering souls. He interprets life by telling what a common experience my be in souls's development. Often the portrayal of his women comes from the lips of associates: Wo feel the presence though we get only glimpses of her now and then.

We should study Browming not because he gives us hidden meanings to be interpreted, and beautiful thoughts, but because in the silent, thoughtful moments, lone with Browning, one gains a sweet reward.

The greatest picture Browning has given us in his poems is that of his beloved wife who is the perfect soul, the "angel of his bosom". This paper does not touch on those poems, because no comment could enhance the picture Browning draws of her charm, her intelligence and her spirit.

Especially charming and tender are Browning's studies of girlhood. They are portrayed in sadness, joyousness, innocence, subtloty and passion. They have their adorable perfections and imperfections. Alive and human, they radiate ardor and inspiration. There is not a character among them that aiternates between smiles and tears.

Browning's favorite girlhood characteristics are gaiety, courage and trust. These girls are not merely half-grown women; they wear a nimbus of shining youth and the "white blossoms in their garlands are immortal". They are buds that do not lose their leaves or beauty and fall among the weeds. 


\section{Characters Pippa}

\section{Poem: Pippa Passes}

Browming gives us an occasional song-bird among women; a Iyric character, whose exquisite emotion utters itself in song; quick, lyrical outbursts from her joyous child's heart. One of the leading characters in the Girlhood group is happy little Pippa, (short for Felippa), the heroine of Pippa Passes'. She is a little Italian working girl "who winds silk the whole year round to earn just bread and milk."

She has but one single holiday in the year, so on this day she rises early, sings to the sunbeams in her wash basin, sings to the purple lily, sings of the happiness that awaits her, sings for any or no reason.

In portraying this lighthearted girl Browning gives us the same child-like trust and simplicity found in Fompilia a total freedom from any taint of worldliness; an exquisite child who finds through her companionship with bees, birds and flowers the way to know God. Pippe is in love with lifes the freedom of the woods, the sunbeams, the leaves and blossoms, the hillsides - these thrill her. Modesty and spontaneity combine in her with an insatiate longing for real experiences. There is an incarnation of love for humanity which at the same time possesses unusual individuality of character. 
Pippa with her unseen and unseeing influence is the central figure destined to affect in successive steps four groups of persons whom she pictures to herself as the happiest in Asolas rising slowly from the rapture of guilty love, through the pride of bride and groom, of mother and son, to the happiness of the love that is devoted to the service of the Maker. Impersonating all these characters in her fancy, she comes upon each of these selected groups at the critical moment and unconsciously her songs cause the turning point in each life Ottima and her guilty lover are stung to repentance; Luigi, the faint hearted patriot, is nerved to stay the tyrant; Jules, the artist, is taught the lesson of self-sacrifice and of heroic faith in his bride: the Monsignor, the holy priest, is impelled to act from godliness instead of guilty greed.

Pippa"s outstanding characteristic is her great purity she possesses a knowledge of good and evil and her virtue is the result of choice. Her purity covers her like a cloak and unmolested she wanders through the groups of coarse students; even Bluphocks, the villain, dares not approach her directly.

She serves Browning"s purpose in teaching the lesson of the importance of unimportant people; the lesson that God knows no distinctions and over rules all things for the best.

Above all she teaches that love raises its standard continually, growing more and more divine, from the shamelessness of ottima radvelly leading upward to reciprocal love between man and 
wife, whence it leaps to the unselfish love of mother for child and finally reaches the love of God, the all-satisfying love.

Browning shows that Pippa is better off in her simple, happy near-to-God-through-nature life than if she had come into her inheritance as daughter of Monsignor's brother. Hers is the upward look; the sweet serenity of perfect faith and the largest hopefulness. She is more like a fairy or an angel than like a human being. Unconsciously she is a messenger from heaven to punisb tho guilty and reward the good.

Browning's doctrines, -there is good in every being, harmony from discord, personality is power, God is love and love is the divine principle of life,-are voiced in this exquisitely dictioned dram.

Pippa's concluding song spoaks plainly and simply to those governed by sympathy and love of humanity:

"All service ranks the same with God

With God whose puppets, best and worst

Are we; there is no least nor first." 
Churacter: Bulaustion

Pootus: "Balcustion's Adventuro"

"iristophanos Apology"

Balcustion, the Mild-pomograncte-flower, is good natured crecture of superb physigue, and a profound philosophor, is a true girl in every rospect. Her urdor, her vorsutility her tenderness and hor lovely sweotneso crown her yeu of Broming's momen. Whon she is introdced to us, she is sitting with pour Girl friente on the barka of a Rhodiun strowis rolating in her meretio manor the story of hir curenturo. Tis fourtech $y$. ar

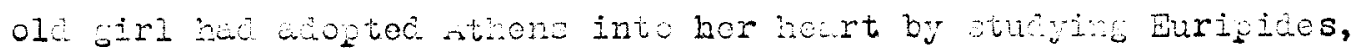
and other Grest poots, so she becano the soul-child of Greek philosophy. Its truts and bewty swy this Iyric gir whe ohe bursts into song whose thowe is the woncrs of art, poetry che Athens. Brilint in intollect we rersitile, she trpifios one of Erowing's aout acrishos ideuls of rown-individucity. The

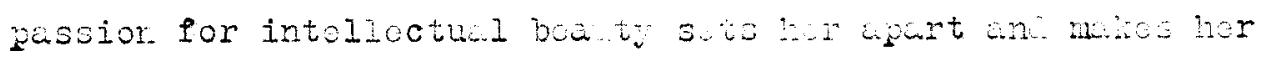

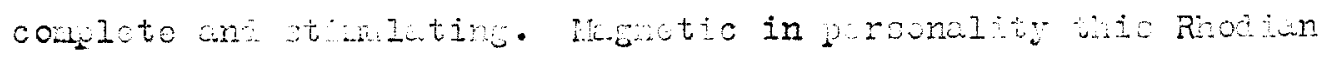
unl with true potritson posuces ho friotenes poo le to

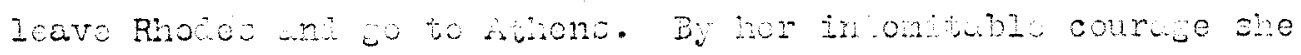

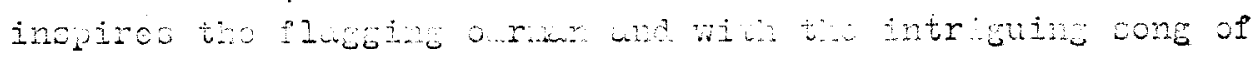
lipe whe liborty wite swod tho athonime at the butte of sel-

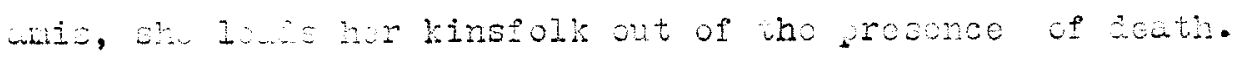

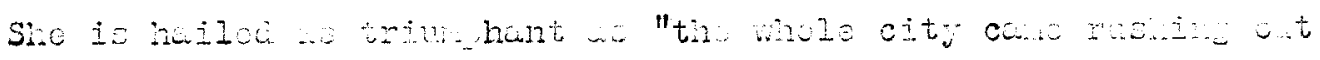
of gates in comon joy to the suburb tengle" to hour tre why of 


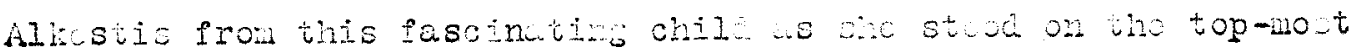
step. Hor sucrificial opirit is buth show when she lowves the

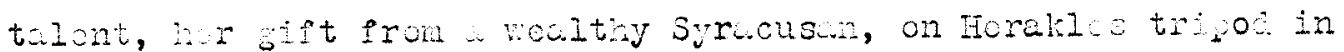
the fune: fur hu not rerckles twice wrothled frow death hor devoted cres?

The youth, we troe duvs atook at the tomplo crinking

in his wrociutton of tho glory o: tho pluy and the ettructito

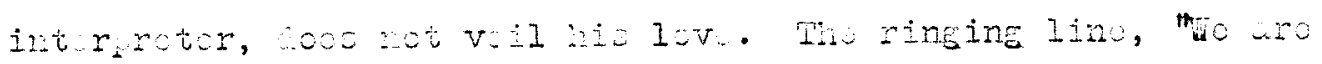

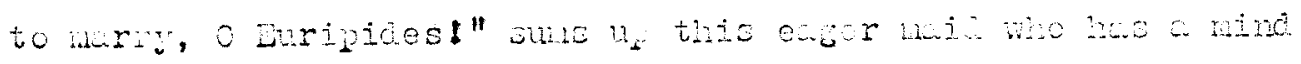
as well as a hurt un sul; he id priestoss as woll ca

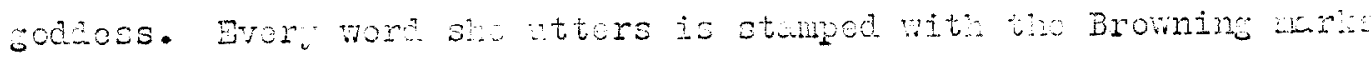
of trust, gaiety, courage and true patriotism that cherishes wost closely the soul of its country. The eacer vearning for the truth and the intensity of bol coreem nt between thes the great souls would scen enough to justif a han marriage. There is no such match mede as the lovers of the sane book! Dante calls it "Loves Purveror!"

A touch of unworthine s and modest; is seen in Dalaustion's coment, "Ah, ut if you had seen te pla itse f!" Fow naturally Girish is the jicture of Balaustim anc these pour Greek girls discussine a suject dear to every girl's heart! Her cl sine conplinent to Euridies is excellont: "Wry crown whon zeus has crowned in sonl befure?" 
In "Aristophones A olog" the wild - ponegranate - Plower has reached its completeness. Belausion is waries to Euthules and together the are seeding across the weters to Rhodes. To free herself from anxiety she rehearses the year's hapenings and he hecowes the copyist. Fer womenly bearing wen she quiets the mot with a from, bears the insults of Aristophanes, and endures his selp-raise, na es Jalaustiun the triumphent woman. 
Character: Evelyn Hope

Poem: Evelyn Hope

This poem pictures the lament of a man who loved a beautiful young girl who died before she was capable of loving in a lover's sense. She is described as being sixteen years old, having amber tresses, red lips, a frank young smile and a spirit of dew and fire. Her appreciation of the beautiful is shown in the reference to her having plucked and placed in a glass of water, a red geranium.

Evelyn Hope is pictured in her opening bloom, with soul so fair and true, and body pure and gay. The man is thrice her age and their paths have diverged Greatly; yet his devotion is so fervent he argues she will not be lost to him. He can wait; he will be more worthy of her in the world to come.

Nothing remains now but the pure white brow and the sweet, cold hand wherein to lay love's last token. So, inside her dainty hand he shuts a leaf which will be a symbol to her of his love.

There is not a word in the poem that hints at Evelyn's possible love for another man. The physical element of love is entirely left out.

Browning brings before us the startling contrast of breathing life and icy death with painful sharpness. Side by side with the fixed and peaceful image of the young girl in her last sleep, we have the warm living girl in her flower-like beauty. 
Character: Nameless

Poem: The Last Ride Together

Sympathy toward a rejected lover causes the girl with

her proud, dark eyes to consent to this last ride and permit a

last embrace. Half-pitiful, she fixes her gaze on him with life or

death in the balance. No line that Browning has written is more

characteristic than "Who knows but the world may end tonight?"

A glance into the lover's heart and mind reconciles us

to believe the girl's conduct was warranted, though Browning refrains

from teaching that privileges of lovers should contine when that

love has been changed to friendship.

From her long silence hope comes to him again: that

expectancy which comes along with the stimulating joy and ex-

hilaration of riding. 
Character: Eulalia

\section{Poom: A Soul's Tragedy}

Betrothed to Luitolfo and the beloved idol of Chiappino, Eulalia, the shrowd woman, is just the opposite of Anael. At the outset, we find this heroine at the home of Luitolfo awaiting the roturn of her lover who has gone to plead with the Provost not to exilo his friend, Chiappino. Eulalia shows a wholesouled magnanimity and a philosophic self-poise in listening to Chiappino, for she must have been very indignant at the charges he mado against her lover. We are won to her at once through the womanly sorrow at Chiappino's unreturned love and her frankness in dealing with him. Yet, we deplore the fact thet she engaged herself to him, eron though a short time to make a study of him. Chiappino found her love worthless, as is all love that is put on to work out a problem.

True to her lover, her first thought is always of him. As a woman, she sees the highest possibilities in Chiappino, but she has no plan with which to raise him. She desires his welfaro and her faith does not die until the last spark of trueness leaves him. The glittering position as bride to Chiappino, the new Provost, pales in comparison to the pure flame of love for her true lover, Luitolfo. Constancy, loyalty and scorn of deceit are this shrewd Eulalia's outstanding characteristics. 
As an artistic creation, Eulalia is a failure; her love for Chiappino was not a natural passion and consequently could produce no natural result. The office of love is to broaden, not to censure; so if Chiappino: should fail in development it wes bocause her pretended passion did not answer the purpose of real Iove. She solved the mathematical problem of proving Chiappino ogotistic, and dishonest and Lujtolfo unselfish and honest; in this she was a sucooss. 


\section{DOMFLEHOOD}

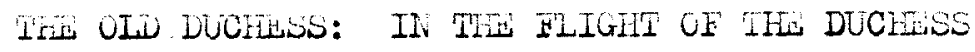

VIOLWNE: WIO BOUGRS PUPPIIIA

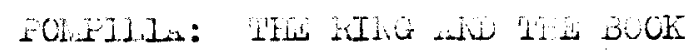

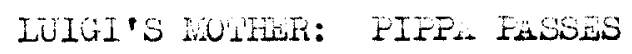

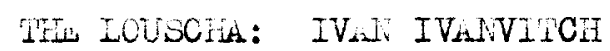




\section{Notherhood}

In Browning's gallery of vomen, he gives us few pictures of mothers with babies; yet, in his caricature of mothers he reaches from the lowest depths to the highest peaks of womanhood. With a masterful hand he depicts the women of the streets, the sympathetic and influential women, the self-centered, cold, relentless women, the lily-white soul-all mothers.

A restlessness, caused possibly by innate responsibility, characterizes each of Broming's nothers. They are wonen alive to the best interests of their children; women who make prompt and imnediate decisions; whose lives have been enriched by the exultant, all-sufficient love of one's very plesh and blood. Browning also depicts mothers dis laying sacrificial love; whose conduct on fleetinc glance volla be temaed imhuman, imossible, but on further thought an act of charity, that zives to the child a better environment, closer, more holesone compeni nship and riper affection. Having know the joy of fatherhood hiself, Bromins, with the utmost symathy and tenderest thought, jictures this sweetest reality-the mother-love for her child. It transforms, exalts and cromns a women's life with consumate joy. 
Character: The Old Duchess

Poem: The Flight of the Duchess

The sick, tall, yellow duchess, nother of the duke, is

a typical dowager of the darkest hue. Jealous of the lovely, flower-

like daughter in-law, she seeks in every possible way to make her

life miserable. On her first arrival, the old mother-cat is described as standing in the rear like a wind to the Nor'ward-cold, repulsive, and unsympathetic. Her severe criticism, her menacing glances and her sharp tongue of censure crush and deaden the life and gladness of the young duchess.

The old Duchess "snielt blood ith a cat-like instinct." Her mission was to dispose of the young duchess so that she might be in power in the palace once more. She left no stone unturned to accomplish that purpose; her gods of life were pover and greed; in gaining these she developed hatred, malice and jealousy. 
Character: Violante (who bought Porpilia)

Drama: The Ring and the Book

There lived in Rome in 1679, an elderly couple, Pietro and Violante Comparini, who were so fond of a good living that they had gone beyond their means, accumulating considerable debt. Having pride, they would not beg, nor did they desire a papal bounty. Times were hard and creditors urgent, so the wife, a shrewd Italien woman with little principle, decides that if they had a child, the estate that wes tied up for the benefit of an heir-at-law could be turned into much needed cash.

Devoted to her husband and knowing a child would please him, Violante secretly visits a nother who was dying in poverty, disease and shame. Money passes between the two and the babe becomes Violante's, who deceives her husband into thinking the child is their own. This child becomes the francesca Pompilia $o f$ the play.

Violante displays as much mother love as those who have daughters of their own. In her testimony, Pompilia said that Violante loved her as she loved her babe; never was there criticism of Violante's treatment of the child.

Pompilia, a marvel of happiness, innocence and affection, brought much joy into the hearts and lives of this couple, who reciprocated her love. 
Beginning with deceit and lying, Violante conceives the idea that a marriage of Pompilia to Count Guido, a man of rank, will exalt the family station. So without her husband's knowledge, the child of fourteen is secretly married to a man mach older than herself.

Garmulous and simple, Violante violates all principles of loyalty when Guido turns her out of his palace and she retaliates by exposing the facts of Pompilia's birth. This is another stain on Violante's history - a most selfish, cowardly ect which destroys the halo which shone around her love for Pompilia.

This character brings out the discussion as to whether or not a lie is ever justifiable. Browing makes nis belief quite clear that it is futile to justify such deceit even when motherlove is involved. 
Character: Pomilia

Drama: The Ring and the Book

Browning tells how, one summer day, by accident, he picked up from a Florence book stall an old yellow vellumbound book $10 \mathrm{by} 7 \frac{1}{2}$ inches, relating to a certain Guido Franceschini who married in 1693 e certain Pompilia who had been brougt us as the daughter of Pietro Comparini and his wife. Guido took her soon arterwards to his home at Arezzo, where for three jears they lived unhappily. According to her husband, Ponpilia was an intractable and unfaithful wife; Guido, according to his wife, was a cruel, infanous husband. Pormilia suddenly fled with a young Priest, Capansacchi, back to her parents. Guido pursued the fugitives, came upon them at the last stage of the journey, and had them arrested on the charge of adultery. Caponsacchi was relegated to Civita Vecchia, and Pompilia was detained in a nunnery. She was dismissed to 30 to her parents' home where she gave birth to $\mathrm{e}$ child. There on January 2, 1698, Guido appeared with four retainers, killed Comparini, nis mife and left Pompilia for dead. She survived four days. The accused were executed after they "wrangled, brangled and jangled a month." Thirteen of the twenty - two pieces of the original document are in Latin "intefilieted witin Italian streaks." From these Browning squeezed every statement of fact they could yield. 
The facts as Browing found them in "The old Yellow

Book" were dead and inert; to five them life, he must breathe his spirit into them. Just as a ring, once his wife's, worn upon his ratch chain had undergone the delicate process of being made beautiful by hamering the ore with the alloy, so Browning decided he could eit the thoughts of "The 01 t Yellow Bool" artistic form $b_{y}$ mixing them with his fancy. The facts of the booz were the jeweler's ore; the poet's fancy was the jeweler's alloy; his fancy nixed with facts - was the jeweler's ring; hence, the name "The Ring and the Book." 
Character: Pompilia

Poem: The Ring and the Book

Pompilia, victim first of the mediocre, ignorsnt, and smallsouled, then of the very devil of baseness, is one of the purest and most beautiful of imaginary creatures known in any language. Too, she is the most exalted type of motherhood that Browning has given us. When but two weeks old, this child of crime and misory is sold by her heartless mother to Violante for the paltriest of motives, money. Ignorant of her parentage, for twelve years in her happy, carefree way, Pompili lives with and loves her foster parents as her own. Suddenly she is snatched awy to be married to base, vile wretch, Count Guido, n imporerished nobleman of satanic lineage whose terms of ondearment vary from spitfire to mongrel brat, and whose embraces were to her as "sulphur, snake and toad." Bought at a hawk's price to do a hawk's service, watched and guarded, her life considered a chattel, Pompilia is such a model of perfection in her innocence nd patience, the cormon people considered her martyr. Perhaps, nowhere in the poem is her merciful spirit so well portrayed as when on her death bed she pleads that Guido be told that she has forgiven him. She cannot have the oternal resentment toward the man who had bestowed on her the great crown that consumates woman's life. 
Vivid pictures of how the rightly spoken word in dire need might have prevented human sacrifices are shown when Pompilia clasps in vain the reet of the Archbishop and begs the poor Friar and Governor for help.

So Iong as Guido sinned ainst her alone, she bore it; but with the first intimation that nother soul was wrapped up in her own she rises magnificent in her strength to surmount in time the wall of freedom which seemed closed against her. To bring up her child as hers lone, way from the infiuence of her fiendish husband caused her flight and no code of ethios condemns her. Pompilia was murdered for money, not honor. The "snow-white soul that angels fear to take untenderly" was reviled by that fury of fire, as child cheat. Charged with falsehond and unfaithfulness this perfect soul who could neither read nor write is accused of having written perfidious love letters to a Priest whom she had seen only once:

See the frail little body black from head to foot, hacked to pieces with twenty-three jagged knife cuts a few hours before her death struggling to live long enough to vindicate her child, har heartless mother who sold her, and spending her last breath bsolving " "lustrous and pellucid soul!" Hear her in her anguish implore the nuns "anywhere, anyhow, out of my husband's house is herven:" 
She is magnificent in her triumph; for when Guido attempts to harm her, she snatches his sword and in righteous wrath denounces the cowardly husband until he slinks away, beaten, from her presence. God thwarts the wicked scheme and 1 aw bears out God. It finds the soul of Pompilia snow-white. The fragile flower is as strong in her denunciation of lies and hellish plots as she was docile first to her foster parents then to the detestable husband until he made her life miserable.

Caponsacchi's reverence and compassion for Pompilia in her despeate need are to be commended. Even her husband's wicked brother, Canon Girolamo, smiled at her entreaties, rearing the result should he offer her help. The burning, meaningful words, "I arn yours," from a priest, showed Caponsacchi's heart and soul. His love is pure, deep and holy: not a passionate lover, but one, steadfast in the face of death dares to show pity sind knows "duty to God is duty to her." Pompilia loved Caponsacchi as her guide, protector, deliverer and a souI mate. Her continual solfcitude that he be absolved from all blame shows her love and does not detract from her womanly spirit which is maintained at all times. The trueness of their love is shown when Caponsacchi tells Pompilia that her life has been a divine benediction to him, leading him to be a Christian. With soul knit to soul he reads in the carriage the Vesper service and she gives worshipful hearing. 
Pompilia's relation to the man who helped her escape from her almost four drear years in that dread palace, was of utmost purity and innocence. To her he was her God-sent means of deliverance from a Iife that was no longer bearable. Genuine unselfishness is her motive. The halo of approching motherhood which is to crown her as one carrying out divine commission makes this "Lady of Sorrows" with her "voice immortal", a picture of exquisite delicacy. Pompilia, the sweetest little mother any one could imagine, lived but two weeks to enjoy the God-sent gift, yet the babe's coming converted her from sufferer to a defender. She forgives everybody; even the satanic husband, who treated her so cruelly. She excuses him as she would wayward child. She cannot have hatred in her heart toward the man who, however inhuman he may have been, bestowed upon her the greatest joy that crowns woman's happiness-a darling innocent life.

Gretano was hers lone, born of love, not of hate. From the very beginning the hope of maternity changes her despair to joy. She sees birds carying sticks and wool for their nests and hears beaty in their songs she never heard before. Jealous lest she lose her babe's first smile, the mother heart held the abe close hoping he might smile before the appointed time-one month. What expectation:

Heavenly thoughts fill Pompilia's mind. She says she never realized God's birth before. She places her babe in her arm just as she remembered lary and the babe, Jesus. Such faith and beauty! 
Pompilia closed her eyes in death four days after the attack by her husband, giving to the world the story from her own lips and speaking in gentleness, forgiveness, and with bravery toward her husband and all who had wronged her. Guido, called upon her to save him and Caponsacchi the worldly priest turned saint under her influence and blessed her. So this fair flower from the lowest muck of Rome is "First of the first, perfect in whiteness." 
Character: Luigi's liotior

Druide: Pippa Passes

The scene inside the ruined tirret on tive ilil bove

Asolo is the most represent tive picture of mother and child

thut Browning gives us.

The son, Luigi, is fifteen yecrs ald; impet ous, determine willing to die for lis rative land.

Feuring his suety, Iuigi:s mother pleads vith hin to put the crime aside; that e rly arorn and not nibit is for aventure; writers must be sens tional; hulf oi Ituly's ills are feifned; s rely she is not so wronged as hus heen represented. Her appeals are addressed to Luigi's physical interests; he is so young; there is no possible war of escep; he has alw rs. been to her the ever obedient son, surely he will not ow he criel and wikind. Then she wrues the futility of one with so unstedy a hand, hot head, whe nervous heart trying to assassinate the King! She even mentions the subject neurest the boy's heart, the blue-eyed Chiara, who is to cone in June. What would she say?

Her ferr reaches its height when patriotisu triumph tirrodgh Pippa's somb. Fis mother knows in his going her sccrifice is necessary for Ituly's freedom. 
$\because$

Character: Louscha

Poem: Iran Iranovitch

This folk-lore tale is laid in the vast Russian wilderness alive with hungry beasts that know no fear. It portrays motherhood's first disgraco.

It all literature there is no better example of cowardice than in Iopcha, the mother of three innocent children whom sho fed to the Satan-faced wolves in order to save herself! Among what monstrous things shall she be classed?

Browning says that the fox-dam will slay the felon sire that dares assault her whelp: that the beaver will conceal her young from harm: could a human nother, throbbing with mother-love, do less?

Iouscha 's sacrificling the puny, undersized, most loved darling first is most unnatural. One by one her babies are torn from her arms by the ravenous molves and she lives! The one and only protection was the lighted twist of pitch which Iouscha either dropped or forgot to use. There is the lack of even brute instinct to preserve her offspring.

Lousche forfeits the right of Cod's divinest giftmotherhood. 


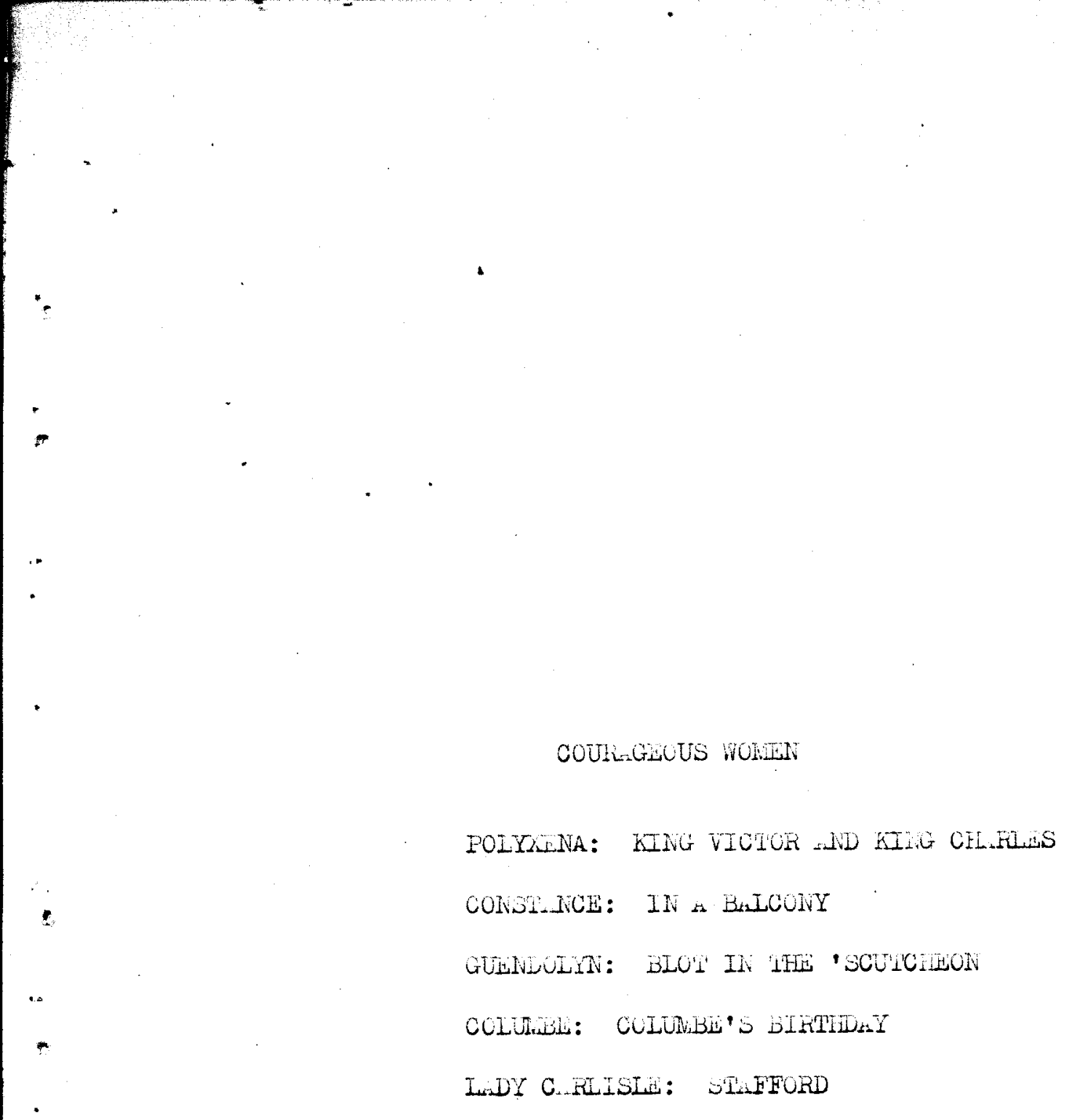




\section{Courageous Womer}

Ever character in this paper chosen as Couracewus, may be fuluc iri tre ciramas. Erownine's ururas containile powerful nassaces are not uf action, but of thoicht. These ontstinding heroines are parted witl ar artist's imachation; their keer irtellicerce und ouruge bride suvine help to mankind. They are womon of power, placed in critical situations; they are îliow-worders, sturdine sile by side of men; thoughtur diwors, brilliant often, their deepest desire is for love; hence, for service. With their cook and evil passions balancine, they are entedive arde, in bingine abou the climax of the story.

Lrowing dejigrts in placing an artful vomar like Constance as a folI we aledr-brained, honet man, us iorbert.

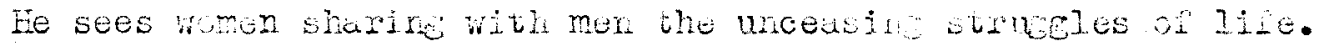
The solution of tho problem mary tines is ut into the Houth of the noman.

In the study of Erownine's aramas we find united the two ereat prinetples which form the foundation of all his best vork: krowledse, which is brownin's philosophy, and conduct, which is his art. 
The representative woman of the 19 th century was prave, resolute, oossessing the authority of wisdom. Her heart and brain workea brevely tocether; she was the counsellor, the comforter, the wise, uardan angel. She possessed intelligence in affairs, clear woman! insight into men and intrigue. Browning, in his portrait re of wonanhood has not been unnindfil of these characteristics, especially in dranatic monologues in which he has no superior in literature. 
Character: Polyxena

Drama: King Victor and King Charles

Browning speaks of polyxena as "the noble and right woman's manliness" as opposed to the extreme sensibility of Charles and illconsidered rascality of D'Ormer. With broad vision which readily grasps and analyzes question from all sides, Polyxena charitably concerls with a mantle of lovine sympathy the repulsive and undesirable. as a wife who has atudied her husband, this courageous woman knows Charles' exrnest good purpose as well as his immaturity of powers; so her optimistic nature endures his wrongful doubts and she becomes his divinely chosen counterpart.

Charles, with his vacilluting will, is a misfit; he would eagerly give up the royal crown for a life of quiet and contentment; but Polyxena, porsevering, tactful and devoted, insists upon his remaining true to his throne which she thinks is God-given. She argues that duty is man's greatest concern, not happiness.

In her understanding of involved court affairs, Polyxena never violates her natural womonliness. Her presence and influence strengthen Charles' self-reliance and discourage self-pity. She has no fear of D'Ormea, whose deceitrul stratagems and lying tongue she scorns. Her dissecting eyes soon ferret the character of the vain, choleric, inconstant Victor.

Eager for the quiet of home life, away from courtly dutiea, the devoted polyxena taces the burden of being a real helpmeet in Sardinien afiairs. Her keen sightedness and $r$ esourcefulness $w$ hen Victor appears to claim the crown and her deft maneuvering of the unstable conditions, place Polyxena among Browning's most courageous women. 
Character: Constance

Drama: In a Balcony

In this fine bit of psychological study, Browning has given us a nature in which court diplomacy, self-sacrifice, passion and worldiness blend in proportion so strangely that critics sre baffled by the resultant womanhood. Only an artist could have molded a character with such a mighty, though orring mind, and a love, the essence of unselfishness. Naturally sweet and attractive, she possibly would not have made the error in judgment had she not been a typical product of court-life, educated to put her trust in political plots and conspiracies. Conceding that Constance's reasonning is fallacious in that she seems to forget that no mortal ever grows too old to love or be loved, her innate longing for success in gaining the queen's consent for the betrothal and her feeling of security in the Queen's affection, outweigh somewhat her short sightedness in discerning the Queen's oharacter.

Fmotional and impulsive, Constance serves as a fine background to the mute, passive, acquiescent attitude of the Queen. Rarely does a smaller nature understand larger one, so Constance does not read the Queen correctly. Ignorant of humsin nature, she cannot conceive of how the withered, tragic Queen bereft of personal churm, starved for love, could be capablo of tenderness of self-sacrifice. Fired with her unoontrollable love for Norbert, the. Queen's favorite, Constance, insists that there is no other way of approaching her majesty except through the ruse that since his heart's choice, the queen, is denied him, he will take the next dearest. 
During the sacrificial soene, Constance with marvelous courage and magnificent unselfishness, offers a complete surrender for whut she considers the good of her lover. Driven to desperution because of her deception, she tries to retrieve her act by reminding the queen of her present bond in matrimony, insinuating even the shame of considering Norbert's proposel.

The supreme test of a perfect love comes when the queen enters and Constance unhesitatingly insults the love of Norbert, thereby resorting to the most desperate means of keeping up the deception. Never once does one feel an exaggeration in the superior force and irresistible power of Constance's love for Norbert. Such love is ages old; love charged with emotion, self-macrifice and courage. Through all the decoption, the keen, satirical remarks and the insults, Norbert realizes his soul is knit to Constance's though the present situation is blinding, indeed. In this perfect union, forgiveness and reconciliation follow though both realize that the queen sinned against, will crush her ungracious offenders in her relentless grasp. 
Character: Guendolyn

Drama: The Blot in the 'Scutcheon

The gnanimous cheracter of this drame is Guendolyn who has the dauntless courage to desert her lover if need be that she ma take her place beside her fallen cousin. She argues that in error the "world has been won many a time, by such a beginning:" Her attitude toward Mildred after she knows of her sin, is the correct bearing of Christian womanhood toward fallen sisters. Love, sympathy and loyalty combine in Guendolyn to make her a capable and forgiving woman. She is the only entirely natural character in the play; the representative of common sense and practical influence. Among all the reak personages in this plot of confused clashing of pride, innocence and remorse, Browning chooses to place Guendolyn as the central figure.

Guendolyn exemplifies the fact that "a friend in need is a friend indeed" that we must serve those who are unfit to serve themselves; that the man who deserts his friend when he stands in need of his help is unworthy to be beheld by the meanest og: She typifies the Good Samaritan binding up the wounds of the spiritually sunken; offering the helpful message which says, "Though your sins be as scarlet, the shall be as white as snow."

Courageous, resourceful and loyal, Guendolyn's character is expressed in her own words, What is done, is done; my care is for the living." To her, one's Iife may be transformed; remade as a piece of clay, fashioned and tried by the amatour until the most perfect 
is attuinod. She endeavore to aucet pace un harwony out of tho hoplese uncosturing, but hor efforts aro in vin bockas

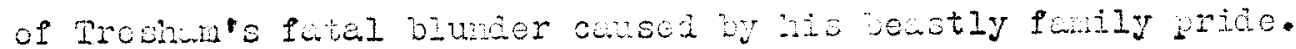

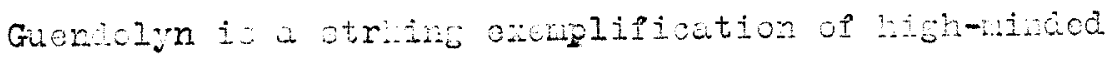
feinino owwon soned, of clow insight into tho truth of thingo. It wa she no discoverod Hilcreds secret; who by hor ow in-

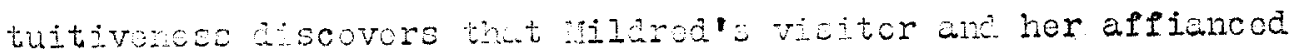

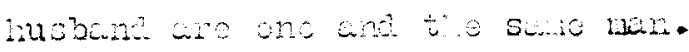

$$
\text { Guentolyn is tho rook on witich wo caw rot in yuiot: }
$$

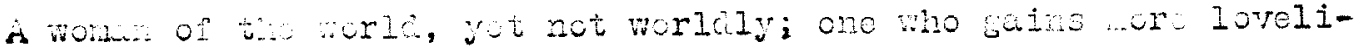

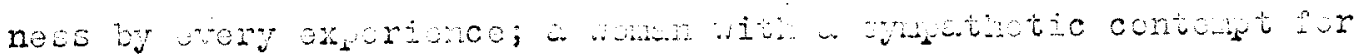

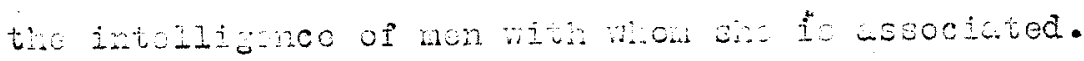


Churactor: Colunio

Draila: Columber Birthiay

One of the wost plousing of Bromingts wonen is this philosopher, a wown close to the universal heart. Sho is ono of the thoroughly good wowen of poctry und fiction.

fll hor hap young life she has lived in a rotired cactle on a rivers brint cnd now wid dpluuse and dononetration she is crowno. Duchess of Juliors. Hor Gay girlishnese, her jovounnese, end her clear, decp, noble nature attract ua fron the beginning - Colubib is first a wown, thon a queen.

Younc, beatipl, Colubo after a short twelve wontis becomes the prey of roval purasitos. Endeavoring to kop fuith in hor fellows, innocont, brive, frunk and contunt, this heroine is the fire and soul of the play. She moves overyody by hy own omotion. In a short tiwe, the real stute of uffirs in hor kingdow is eisclosed; she oxperiones the utter worthlessnoss of court affectious, yt she is lowth to wrt with hr ducul crom. Berthrold, the rightel prince, appoars with a ereater clatin to the throne. Untouched by love or tive futes of her pouthion, sho cuddenly finds horself in tho midst of a wirlyool of affars and love.

When Valence, the hero, a poor actocute who loves hor, cones to pleat the cuse of sufforing wen and prosent wo wrongs of his toms-

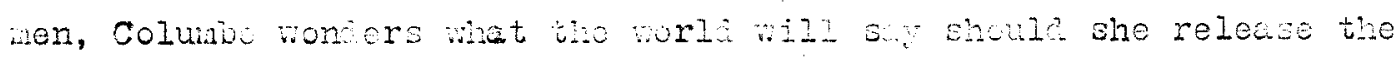




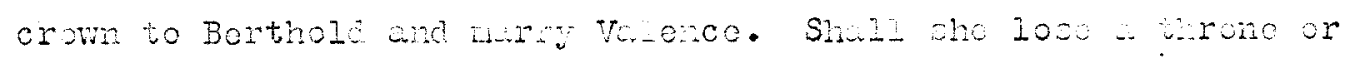

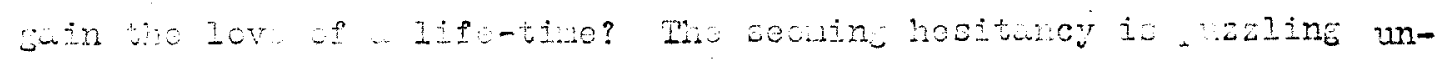
less one finds aky lutor ivon i. the erwa-colube ha nover beroro dures to look within horspli. Mabening affection intse peuce.

$$
\text { Broming ives nis inilowopy of love through Columbe: }
$$

Lovo id the divine pringise of hum lifo; love is f.ith and thore in no subtitute for it.

$$
\text { colume's bolien in lors brings her ont of the choe, froo }
$$

and unstiknot by a singlo move on ill-fesling or weun thinking,

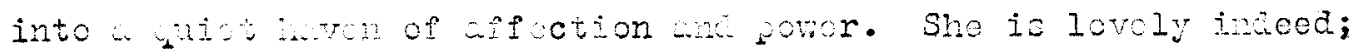

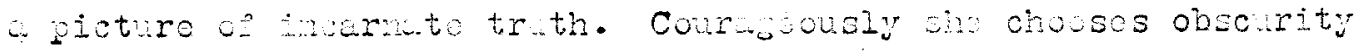

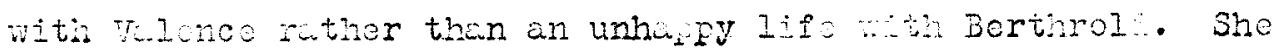

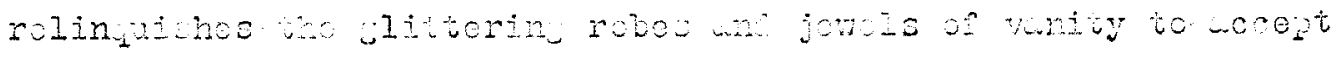
the lo\% of thus tro.

$$
\text { Colwio ro, some a prescribed model o: wominow won }
$$

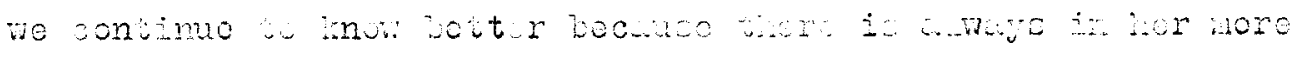

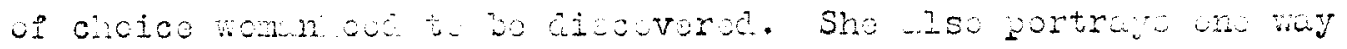

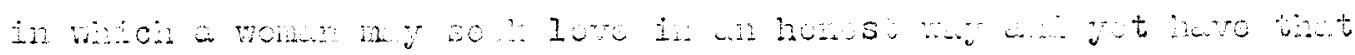

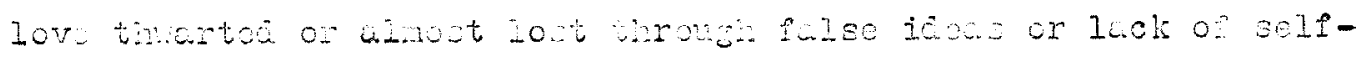

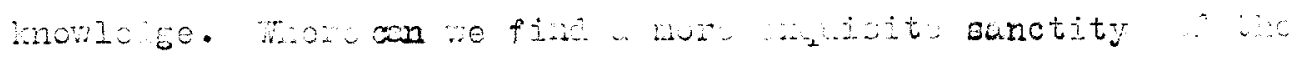
wown than is affused like is pertue ti.rowh Colmio? 
Character: Loy Corlisle

Drama: Strafford

There is in wonderful rocewblance in the invented Iady

Carlisle which history urmises ruther than describes. Moro is

the sure inclintion to fix the hourt on the grest min and to serve him vith no return of afection.

Lucy Percy, Countess of carlicle, while brive ond courageous as aro wll women who scicrifice thensolve to wen who do not aprecite or uncerstane them, is lacking in ealfavortion.

A wonn is enpoced to hure the cumpenstion of boing at least a unit by hor husban, but for her to eink hor indiviauality to prowote the intorote of hor husband is bevond all reason. Undoubtcaly, we curos for stuford but luck of vill powor kess her frow taking docinoc stinis.

$$
\text { Stafford solftaly docete hor sucrifices of hr tiwe, }
$$

tulonis und attention vit: no theight of ever reciprocuting her

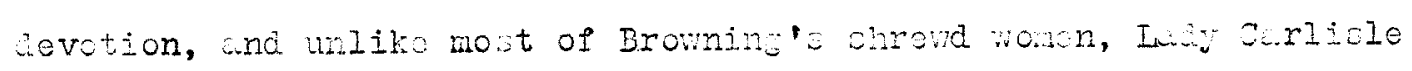

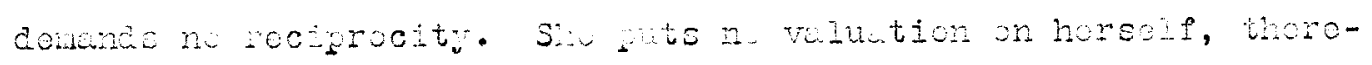

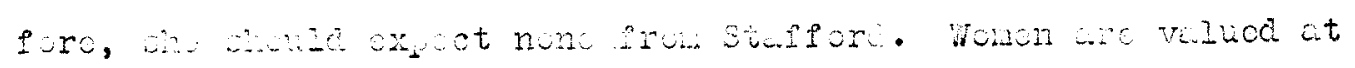
their own abthute of thouse-vos. ICr solf-mbegution sacrificos

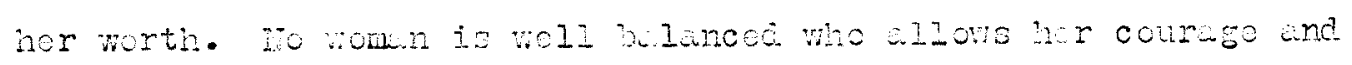
boloness for hir lorer to outwoigh ar a welf-respect. 
Wavering between her devotion for Stafford and her own selfish interests, she reveals Charlos' real nature to stafford. At last she resolves to denounce him to Queen Henrietta whom she angers, so Lady Carlisle imediately retracts and rexerses her decision.

Lady Carlisle's love is constant enough to dare to save him and her plan of eoscue is ready to be carried out; her unrecognized anc undeterred devotion is tenderly pathetic; it has a courageous dignity of fatthful service rewarded only in serving. 
FAITH AND CONSHACY

HUEL: RETURY UF TFIE LRUSHS

LVIRE: HIFINE AI IHE HIR 
Faith ana Constancy

Love is the fulfillment of the law and faith prociuces love. These two theories of Browning are exemplified in his faith and constancy poems.

In his poems which treat of Love between man and woman, Brownine reeurds the union of soul with soul as the crowning achievment. Above all things love is needeu as the soul travels upon the uncertain way. He argues that love is the only secret of a victorious life, and that love and life are purified and made richer; wider visions of spiritual experience are pened.

We aumire Brownine for his dionified seriousnesi,

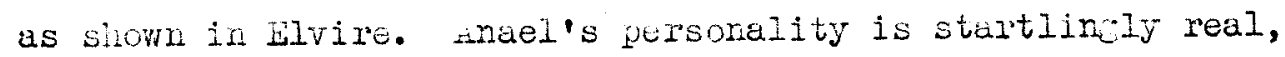
with her keen, pentrative intuition. Both are women exertine a ereut inspiring iufluence upon the men who are ceurest to them; the f are intellectual with the power of choice. They choose to be true and loyal, in their creat love for each other a fact which Brownine says is the whole secret of a happy wedded life. 
Character: Anael

Drama: The Return of the Druses

Of 211 the heroines of the great drama, none is more interesting than the Druse miden, Anael. She is typical of the women Browning has revealed; eager, complex, capable of growth, liable to fall. Beloved by the Druse leader Djabal, and sister to Khalil, Anael is the picture of heroic faith.

Kept hidden by her mother on account of the fate of women possessing bauty, no wonder this simple minded girl, looking upon Djabal and his elegance for the first time, should think him some supermatural being!. Loving him with the intensity of a passionate nature, Anael believes implicitly in Djabal's divine claim that he is Hakeen, the Messiah, the God incarnate; yet, and here is the cause of his suffering, she can feel in his presence only a deep human love. Her heart pleads to love him as a man, not a deity. How human, that she craves the God Hakeem, yet is unwilling to relinquish the man in her lover. She cannot kneel to him. He seoms no God. What astonishes her most is that he loves her for the purely human qualities. He demands no goddess. She is pure, true, and tender, yet in contrast, she is weighed to Barth with a sense of spiritual deficiency. Her innocence shows $D_{j a b a l}$ his own deceit and treachery. Although she is but a ohild to him, ho cannot tell her of his guilt.

Doubt arises and her consoience urges that she must not become the heavenly bride without confessing her doubt. That Hakeem the omnisoient should be surprised at Sir Loys' return, arouses once 
more Anael's uneasy doubt. She tries to keep her agitation from Loys to whom she is sont by Djabal. The love scene between Anel and Loys excites one to ity. With the fervor of a devoted lover, he pleads his case in vein. As she has vowed, she will marry the one who raises up her tribe, restores its ancient rights, and destroys the tyront Prefect.

She decides both mon are human and tells Djabal she know when first she sur: him. The unfeignod simplicity with which she surrencers to Djubal is chrming. Hoved to is stute of religious fervor to prove her utter belief and show her fuith, she stabs the Prefect, culling on Djabal to change her und hia into spiritual forws as he ha pronised. The afterm th is pitoous. Bitter is the sufering whon porsonal love olashes vith universal righteousness. This is the agony of Aneel. Fuith is lowt, but love rebains. Djubal's refusal to confess hio sin to the Druse nation stuns anael. In the two enotional states, religious enthusiasu and her own wowanhood, we see the latter only in bits. Tow will she wet in this crisis? Her choration of Djubul causes her to seek atonewent in decth. Ancel, with a grect tide of tyrannic love and with a poignant life-surrender, hails Djabil co Hakea, thereby renewing the foith of the tribe.

Ancel illustrtes another of Robert Browning's theories that man has absolute neos of women's fath in him, if ho is ever to lourn the use of free will in nor.l cotion. Faith in man is the crowning blosson of eIl philosophy; the grend feith which sees and 
yet believes; which looks uith open eyos and believer in gite of fults, orrors, ono sin. It is only in such a faith as Anool's thet con ver ingire wan to reach townd his highest possibilitiss. Thus anel takes hor place swong Browning's faithel

women: a charcter pull of nobie impulses you beset onc vonulished it the lest. 


\section{Character: Elvire}

Poom: Fifine ct the Fair

Elvire, the true, is the oybol of comestic love. She is

Iand, the suf, colid earth, not sod. The Venetien carnivil, with

its glitering lights and humin bubbles, is a carnivi of human life.

As Iviro, the potioss wie, wolks beside her truent-

thoughtod husband t the pornic Fair onc sees his fecrloss interest

in the bespangled and light hoded dancer, Fifine, she shakes her head, with a welancholy onile and brathes oigh thot is almost a

sob. She realizes the contrat butwen he fuiry form who brings

sunshine upon hr stangled hig" whe her ow glainness wh sher

temprawent. The cheru of a Bohewion lise, the soyety of the circus and the troubled look on Elvire's face, encourages the hubbun to launch forth on araktic discussion of the fidelity and infielity of douestic love, win uleost too front ex licitness. With buted brewth the wifo listens cne with pelo finger, resses the aru of her husbare whose candic curintion of aysy rope daner is the wotif of the oen. Ho wrues thet wa shuld live the unrostrined,

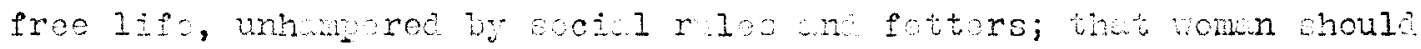
be a fixed ster, constunt and true; never revoltine, dweys stedfcot. Dlvire is the peture of nturel, ovy der womin; she is not a heroine tre nor dono sho poses commding trats. Hor disposition is affectionate no like every wowen who is devoted to her husband, ele canriot supprese tho tine of joclousy thet tnveribly

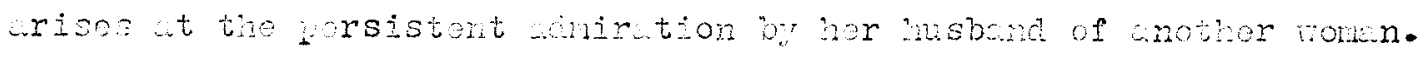


The raccelly husbend, with his fallacious recsoning, represents fichle, if not recily loo:e men. Those who, by racticing the untrue, learn the true. He argues we get wisdon frow even a physical sourco; thet one nky be untrue if thoreby inconstancy is learner. This arsunent is loet on his faithful wifo who knows that it is isnorance, not knomlogge, that lewrns through ovil. Tho wain thing in lifo is to bo true bocuuse this helpo to bring wartal happiness. She drouds nothine so much as inconstancy. She seee gool in nothine that hos not pormoncy.

$$
\text { Brownine tecches that temporiry inconctancy ma be pro- }
$$
ductivo of goo, for when trire and hor husbin? reach home the Don tells his we he has larnod his lesson; ho wants no wore of the lighthobded Fifine, "Love is uli mi death ie nought." 



\section{Unrewarded Love. \\ Jrowning did not write half as much as other poets} had. done of the love between man and woman. In his poetry there is not that exultant, satispied note which one encoutors in so many poets. The nere love poen is no main element in his work. Nowhere does Browning teach that love is selp-contered. Beins a keen, healthy observer, he is woet of life and tells how a comon experience may develop a soul. Love is the only secret of a victorious lipe; if it is wistaken or unreturned, there is a sickening air of hopelessizess and helplessress. Then love is lost, all is a failure. Nobody reguires all heroines to be a success; some rust fail to je true to life. In this group of unrewarded love some women have failed because of their own lack of soul response; others, because from the begining something besides love formed the comerstone of the life's building. sroming was gifted in writing the unexpected; phases of life under guick thought and sudden passion becane transformed from the comonplace into extraordinar $y_{i}$ existence. 
Character: Duchess of Ferrara

Poem: in Last Duchess

A typical bond woman of th Eeneissence is the suject of this nasterful poon. The grl blossoming with iresh beanty and ignorant of the world's coldness, is full of love and clinging tristpulness. Her youth and frank hapiness make her a favorite with all Wut her egotistic husband, who, in trying to mold her after his own conventional fora, crushes out hr hope, her love and her life. Fe didn't like the way she siniled; so he strangled and threw her into a durgeon.

She is dead and the Duke is negotiating another marriage. Without emotion, he drows back the curtain wich covers the picture of the Duchess. This tycal autocrat of the Reneissaice, with his self-conosure of selfishness end Eenuine devotion to art, gives a sketch of his wis to this enissery of his new father-in-law. Te see "thet s ot of joy", the foint blus? rought to the far cheek Dy "such stupi as, courtesy"; hr e.es, tod, eager to aiss none of nature's Deauty, follow the onlooker; her answerins sulie, so sweet anc wiming, with wich she acmowledges the slightest attention. The sane snile thet enraged the Duxe. Wit timate conosure he boasts of stopthe the eniles ali togetrer.

The piture ropesents conditions were women is chined rethor then frees , moriag. 
Character: The Queen

Drama: In a Balcony

The Queen, a political machine, surrounded by willing hands, swift feet, and staunch hearts to do her bidding, these fifty years has been loveless. With a calm and queenly deportment, belonging to the regal state since a child, her life has been lived without the endearing affections of loved ones. Versed in political intrigues and court inclinations, she knows that "There is no good of life but love, -- but lovel" All else is a shadow in comparison.

She takes her cousin, Constance, into her home and heart that she may know life through love. She sees the strong bond of affection grow between Constance and Norbert, but she secretly loves him because of his nobility of character. The contrast between the inward and outward state of the queen is so unmistakably drawn as to render her overwhelmingly tragic. Her stupidity in misunderstanding or misconstruing Norbert's appeal for Constance's hand, is unforgivable. Yet pity is felt for her because she is prematurely old, lonely, unattractive, with an immense heart capacity, unsatisfied, though she is married. She yearns for the love and companionship that only a soul-mate can give. Grasping at her interpretation, she decides that we are made for happiness, that God is good; "How soon a smile of God can change the world!" 
Tho strenth of the queen's passion is evidenced by her willingness to dissolve her former marriago; this signifios a childness mind,grasping for the desirad object. Her indiscretion raaches its crast, when failing to follow tha gloam of light that would have cloared the situation, she throws herself at Norbert, hoping yot to win him. Whan she awakons to the reality of her lost ambition, when she sees heaven open only to close upon her with cruel force, no wonder har affoction becomes a retributive spirit of just indignation and malignant hatred, and like a starving creature, wild with hunger, she falls upon her proy: 
Character: The Young Duchess

Poem: The Flight of the Duchess

Just emerged from a convent, the beautiful, young Duchess thrilled with eagerness to know life in all it beauty. She loved the movements of the leaves on the trees, the birds in the heavenall things in nature and humanity. Vivacious and gentle, longing for companionship and love, what a help-meet this fairy-like Duchess would have made with proper environment and a thoughtful husband! Instead, the sight of her husband's face, so stern, and so unsympathetic drove back the joyousness of her own, like a glad sky after a north wind. His superficiality and devotion to ancient customs and traditions causes him to neglect this little wild bird, alive with life. His criticisms and taunts in a few brief weeks change the once tireless maiden into a cowered, list1ess, shrinking creature afraid of her lord, his mother and herself: She becomes a prisoner in a strangely twisted net-work of artificial modes and forms, starved for real life.

The psychology of such an instant, complete change is difficult to understand, but there is no misunderstanding nor misinterpretation in the scene between the gypsy and the young Duchess.

Browning's favorite theme of personality is marked in the character of the gypsy queen. Through deep sympathy and love, the young Duchess is lifted entirely out of the commonplace, deadening existence into the full freedom and all-embracing love of nature. 
The young girl who has faced insults, humiliation and pretended love makes a joyous escape from the false to the true life. Urged by a kindred soul, the young Duchess finds courage to flee the conventionalities of life which have robved her of all individuality. She chooses the right to live her own unfettered life. The divinely human principle that love is the fulfilling of the law has proved true, against the myth of self-destruction and crushing out of life because of disappointment.

The gypsy represents a great deliverer who comes to some in this day burdened with deep conviction or work; she lightens the burden and leaves the soul free to choose. Browning himself played a gypsy's part not long afterward when he delivered a certain little frail body from an atmosphere of pain and darkness on Wimpole Street and transplanted her into the sunshine and health of Italian skies. 
Character: James Lee's Wife

Poom: James Lee's Wife

The problem of love mistaken and unrequited, pouring its golden grains on a hopelessly unresponding nature, is discussed in this song-cycle of nine poens.

We learn the story of this discontented couple from the wife: the husband never speaks and is but one time present. Browming portrays to us the moods of nine separate days-each a wil deploring everything in general; the weather, the inconsistency of man, the unsatisfactory study of art, and the signal failure of marriage, at least in her own case.

Janes Lee's wife is a plain woman, having faded hanks of hair and coarse skin, but we find that her beauty lies in a doroted heart and an intelligent mind. Her soliloquies are revelations of the events in her married life, beginning as they ond, with an earnest wish that love were an abiding thing.

"At the Window" of their wild little place near. Pornic, close to the sea, she aweits her husband's return. In. the dreary comment on summer's passing she blunderingly asks if he will change also. When the embrace comes, without much thought wo guess what is lacking.

"By the Fireside" she broods upon the contrast of a sailor's life and her warm, safo home. She shudders as she imagines some wife who found her husband's love gone. 
She looks on the water "In the Doorway," which suggests to her heart departing fortune and coming disasters. The swallows will soon be leaving. From the scene however, she receives solace and rest by her reasoning that she and her husband have a four room house, the field and love.

In fanciful mood, she walks "Along the Beach." He has grown weary of her wisdom; she has shown him too much love; been too solicitous; the bond has been felt. She recognizes the smaller mind to which she looks for love. The imagination of James Lee's wife is exquisitely poetical, but the weary wiling of unrequited love is nevertheless doleful.

Leaning back on the short, dry grass "On the Cliff" she looks at the baked grass and idealizes the cricket and a gorgeous butterfuly, wondering if the minds of men might not be transformed like them. She is bitterly resentful of the poem she is reading because it depicts her woe and anguish; on further thought she docides the young poet will some day learn the truth. Change is the law, the very essence of life.

"Among the Rocks" she learns the same lesson from good old earth. Each element wholly joys in the other. From this comes the simple doctrine that love is self-sacrifice. "Make the worla better by your throes." "He who loseth his life shall gain it."

She turns from the coarse hand of the peasant girl to mold her perfectly modeled clay cast and catches the lesson of 
uncerstundine; be worh of Plosh end blood. Jeprivod of earth's ideal, we will who bewnty out of hor homely houe butios. Prhaps hor abserec night be better than her presence; so we finc hor "On Deck" where she has set hor face like a rock. Sho knows too wein her huebnets iovo has cone; wo why stay whot

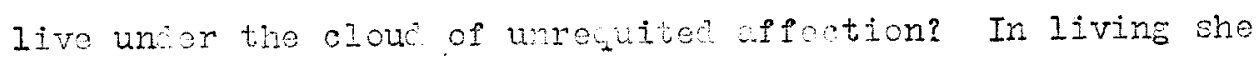
resigns hercelf to hr loss, knowing thet is no balm for love's wound. 


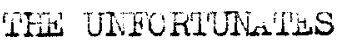

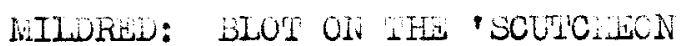

GIRI IN THE CUNHESSTUNAL

WIFI OF RIC.RUI: THE STLIL 2 DND THE BUST

OTIINA: PIPF. FANSES

I.BBY BR.TTS: NH BWLATS

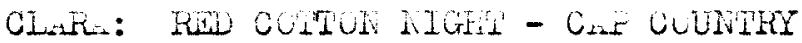


In order to chronicle the stages of all iife, some of aroming's wonen must be jictures of dout and despeir. Because of the numer of victine or fajures, one is led to velieve that 3rowing liked to dwell on the wayward sice of woman's nature. Some of these women, dengerously alluring in their jeanty, are placed in critical sitnations whore the wust act under the ush of quick thought and sudcen passion. Hith little reose in any of these poens, Browing eketches them mith a water hald. None of them have the characteristic of tinidness - all are tenae with feeling anc burning with enotion; vet the are women who are not wholly sac.

Browning cress the snject of these sufferins souls with resolute courage; he does not wate woris and makes no apolozies. Thatever nay be his attituce an wessage for tile saint or s0od, he pleads the cause of the fallen ss pew other po ts have cone. Ee preaches the etemei abotrine of the second chance; of the ceaseless strugle toward a life of purit, hovever far she way ve from it. There is no foilure if we but strive. The world is still ingerpect but we orow surituel in truing to vain perpection. at no tive does Erowning excuse or conceal enoruiti of sin. 
Charecter: Iildred

Drana: $310 t$ of the 'Scutcheon

One of the inost charecteristic marks of Browning's portrayal of woran is his admiration for individuality. Under whatever nane we might class Mildred, she lacks individuality. She serves as a background to the wore injortant characters. Usually, when Brownins presents a cheracter in the sri, of cjrcunstences, he gives her woris to express herself; ut in the character of lifidred he pesents her only as others see her.

Iildred, the iclolized sister of zoung Tresham, has ieen concerned in secret criminal intrigue with the young Earl of wertor. They intend to condone their guilt by marriage. Both are, at the outset, lofty characters with the noblest feelings, cesperately in Iove with each other. Since they belone to the same station in Iife, there would ve no uestion concern'ng their union.

Mildred is a sensitive, highly-organized yet docile creature. She is one of thoe unvalanced persons without poise, whose noral sense of right and wrong is so reafily influenced that she does not realize thet self-respect, once lost, nay, $b_{y}$ discretion and humility be won back agein.

The first uestion persons with reason will asle is low wildred with her enviroment and training could have stooner so low? We take refuge in her imaturity an inex prience because he had never known a mother's care. Jeneath the threat of hor fate she is heIpless and hopeless. Her trusting and reserved nature would lead 
her to be slow in criticizing conventional ideals of life and honor. She Ioves for love's sake and continues to the end to be lost in her Iove.

Her secone fatal mistake is in the falsehood she Ieads her brother to believe when the confesses that her visitor is not the Earl, yei she is going to warry the Barl. This deceit lowers her morality again.

In this hopeless tangle, her conception of Lerton as a lover comes to nothing because of the family pride of Ireshan. Mildred's reworse is of innocence; the mental suffering of one wholly unversed in sin's guilt. Courage, and resourcefulness express themselves in her last vords. "My care is for the living." 
Character: Nemeless

Poem: The Confessional

The Inquisition in Spain is correctly presented in this poen, "The Confessional." Absorbed in her com lete yielding to the man she loves, and having been pronised that woth of them shall be purged by pasting and prayer, this retty young girl is incuced u. her con-wearded, decetful priest to obtain from her lover, Deltran, secret knowledge that is injurious to the church. For her pains she is put into prison and presents a pitiable figure, grim and gaunt; youth, happiness and faith in her pellowman and church are gone; onl $\mathrm{v}$ shame and a "poor wrenched bod" are left her. Watching her Iover's execution from her prison wincow, the girl denounces the disloyal priest and the methods by which she has been deceived. The religion wich cloaks a nen so vile receives its share of hr abusive censure.

The Gospel of Ex, ediency is portrayed in this young woman. The result is the swie where one dares not reason out one's own theology. 


\section{Charucter: wife of Riccarii}

Poom: The Statue and the Bust

In 1687, histow tells us Roruinand became Grane Dure of Tuscary and ramied a Thenon lidy, of the llowe of Iow raine. Gaily the Dure is his ian way, woty and fire like a swordess, sheath, was by the palace of Riccard, nis minizter, on the lattor's weding day. The bride, standing near a window, sose the Dule and they fand despretely ir love with ach othor.

Tho Ricourat, pellowing the Italian eistom of jolous

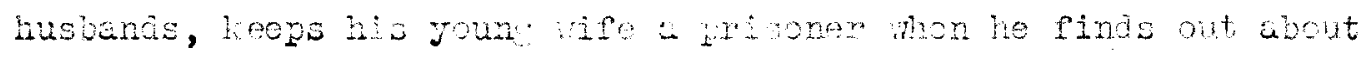
the clandestine love affair. Sho dave ho can assune an easy

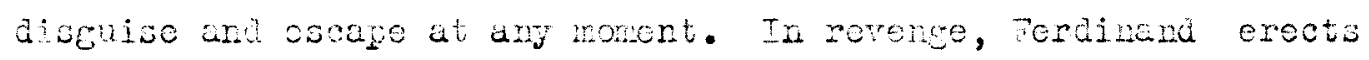
his bust in the square that he misht almays appor to be matching the fair one. The but ras made frow canno taken from the Turks by the hishto of to sterew.

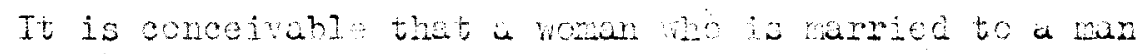
sho does not love nay son her whole life dreaning of the wan she

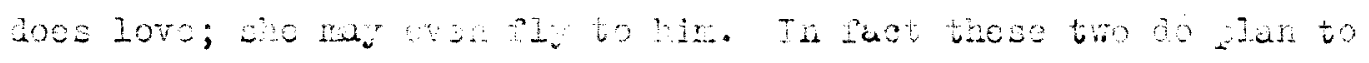

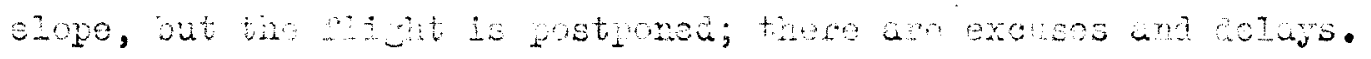

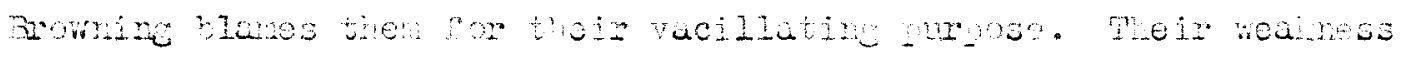

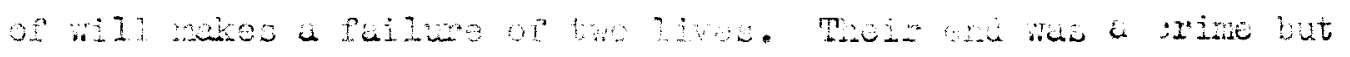

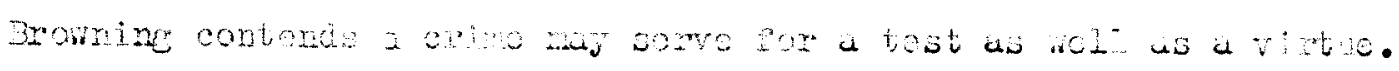

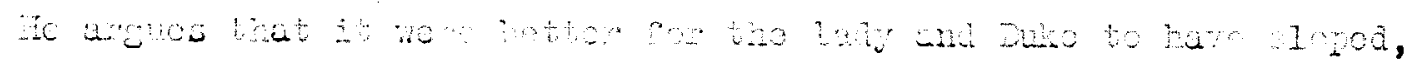

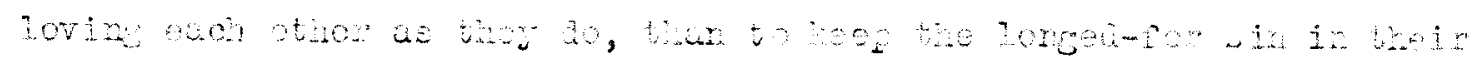
ginde. "Low wh, ail is won" tove to recesary for por foot wrelopuento o? sot.

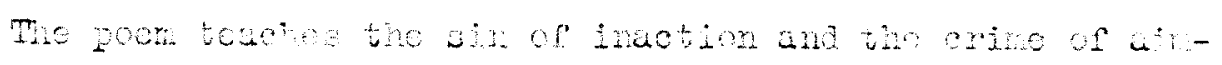
Iessness. 


\section{Character: Taboy Bratts}

Foen: Ned Bratts:

Taijy Bratts was the degradec wife of a man who kept

a tavern that was known to an asseming place for murcierers, thieves and rogues. Indeed, these two were confessec nurcerers. Tai is described oy her husband as "orass-Dold, brick-built

of beef an beer." In their own languare they are the worst rogue couple unhanged. Tab, in her courseness, reeks with filth; she is the lowest suecimen of womanhood, corrupted with irreverence, profanity and irunkenness.

She goes for sone lace to the rison where junyan is confined. He reprimands her for the wicked life she is leading and likens her to a tree all sloughe about with scurs, blasted bow and bole, yet with vital se. on the insicie. Astonished that such a character as Junyan should notice and want to lift her frow her life of degradation, she acce,ts the jook, takes it howe and she and hei read and selieve the worcs, "Ioo: unto me and se saved." "Be your sins as scarlet, wool sliall trey seen like, althongh as crimson red, yet turn as white as the driven snow." Mhe child, who before her reform was not a love babe, now becones to her a little angel. Jrowning shows that affection however crude, way exist between a wile and husband where there is not the slightest respect. Too, there is saving power in Christianity and it reaches the foulest. A realization of ignorance places us nearest to knowlecge. In Tab's case the acceptance of the spiritual life recuired a strugsle. 


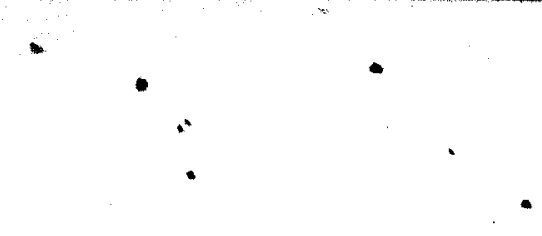

Character: Clara de Hillefleurs

Poen: Red Cotton ight-Cap Country

Child of Jominique and Jaglalen Comercy, seventeen year ola clara in descr tive teris reveals her growth from grub to yocock outterfly. Youns, fascinating, and pretty, in cerly life, she selis her honor before she recounizes its worth. The bage of poverty was borme when, too younc, she merr ed Jlysse Tuhlnanen, who possessed youth and intelligence and wes a tai? or ou trace. Un rinciple, and des erately in need f noner he mula have traffice his wifo. Fleeine to Lanon, Clema Iives in a luxuriously Iurnished mojic apertient, having accotted noner iron carlino. Mirene, the son of the grect paris bulsuith, o.cones jreati, enenoures of clars ond as a means of eccompishing an end, she reveale to him al hor shadowed gat. For

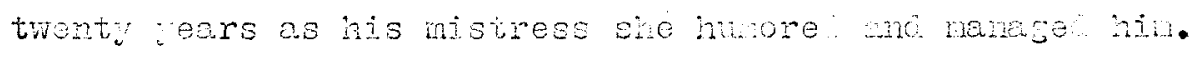
Besrne insults whe a Gto frow those wo uncerstow, clara pore herself with potience end subussion; niranda even so far forgot hinsui as te criticize an disieger her. viot

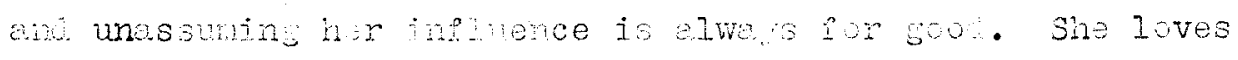

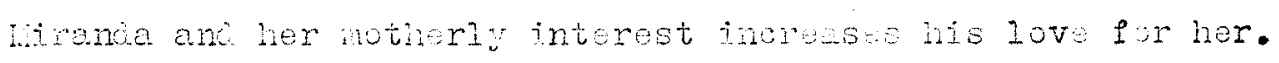
clare's devotion to hi apter the seine episoce con never .e westioned. Even anter he luges his heid into tise ijre to uree himse f of her tmee she takes him wack. She is 

Character: Ottima

Drama: Pippa passes

ottima, the great white ueen by her own triumphant clain, "inagnificent in sin," and her episode with sebald is one of the tremendous things i. English drana. This scene reaches the highest tragic utterance in Browing. A young, jeautipul Italian with splendid shoulcers and "hair with a cast of life in it hal become the wife of old Luca Gadit and the mistress of Se Jeli, a German. Her fearless spirit, and her eir of self-importance are at tines to be admired. Ever: sentence she utters shows her the excessive, cernal wonan that she is. Dee, in the soul of this manisicent, erring creature, lurise the strong belief that "the wages of sin is death", but she wili enjoy the present, and wark of the evil diey as long as possible.

Temptress of her weeker vercuour, whom her indiscretion has dragsed into the murdor of her husband, ottima gloats over the deed and encouraces sebald in stirring, possionate words to crown her his greet white gueen. At this monent the words of pippe's song:

"God's in Iils heeven

Ail's right with the world"

Ploat up to the two guilty lovers. Sebald sees that virtue is better tha: vice, purity better then lust. Instantiv all beauty in his sight, leaves her; his love turns to hate; she is the pitianle, wretched wonen cowerine before the just wrath of God and the man whom she has so cruelly wronged. 
We are shown one germ of goos in her, which wight be enlarged to cover the gross mistakes and inurity in ottima. Just at the moment of death, passion is overcome and for a short time unselfishness and remorse are shown in the words, "Not me, to him, o God, e merciful!" She would take upon herself alone God's punishraent of their joint deed. Receemed at last, her love is chaste and pure and rises to the supreme heights of self-abnegation. Browning's theory that personality is power is wesented in the character of ottima and this scene is one instance in which Erowning's ethics and art join. 
Alexancer, $\pi$. $\therefore$ "Intmoction a Broming"

Bercoe, Edward "Brumin's Orelonedie"

Brooke, Stoprord "Poetry of Rert Eromi ng"

Burt, Nery "Promine's Fonen"

Chesterton, ร. T. "Zobert Browine"

Clarice, Eelen A. "Brownine and His Century"

Cooke, George "Gidebook to Broming"

Cury, Sarn "Bromine end the Drenetic "onoione"

Gross, ‥ T. "7onen o: Bromin"

Homorodke, Z. B. "zine onk the Boon"

Marne, J. จ. "Brownin's Teroineo"

Porter ond clarl "Poet Lore": Vols. $1,2,6,10$.

Symonà, A "A Introäuction to the Stude of Broming" 